Int. J. Dev. Biol. 55: 719-729

doi: $10.1387 / \mathrm{ijdb} .113373 \mathrm{af}$

\title{
Mammary gland stem cells: current status and future challenges
}

\author{
AGLA J.R. FRIDRIKSDOTTIR ${ }^{1}$, OLE W. PETERSEN ${ }^{1}$ and LONE R $\varnothing N N O V-J E S S E N^{*, 2}$ \\ ${ }^{1}$ Department of Cellular and Molecular Medicine, Centre for Cell Biological Disease Analysis, and \\ The Danish Stem Cell Centre, Faculty of Health Sciences and \\ ${ }^{2}$ Cell and Developmental Biology, Department of Biology, University of Copenhagen, Denmark
}

\begin{abstract}
Distinct subsets of cells, including cells with stem cell-like properties, have been proposed to exist in normal human breast epithelium and breast carcinomas. The cellular origins of epithelial cells contributing to gland development, tissue homeostasis and cancer are, however, still poorly understood. The mouse is a widely used model of mammary gland development, both directly by studying the mouse mammary epithelial cells themselves and indirectly, by studying development, morphogenesis, differentiation and carcinogenesis of xenotransplanted human breast epithelium in vivo. While in early studies, human or mouse epithelium was implanted as fragments into the mouse gland, more recent technical progress has allowed the self-renewal capacity and differentiation potential of distinct cell populations or even individual cells to be interrogated. Here, we review and discuss similarities and differences between mouse and human gland development with particular emphasis on the identity and localization of stem cells, and the influence of the surrounding microenvironment. It is concluded that while recent advances in the field have contributed immense insight into how the normal mammary gland develops and is maintained, significant discrepancies exist between the mouse and human gland which should be taken into consideration in current and future models of mammary stem cell biology.
\end{abstract}

KEY WORDS: mammary stem cell, cellular hierarchy, mammary stem cell niche, microenvironment

\section{Introduction}

Like other organs, the mammary gland is formed during embryonic/fetal development, but is unique by being a highly dynamic tissue, whose major developmental processes takes place during puberty and pregnancy. In addition, from puberty and onward systemic steroid hormones inflict changes in the epithelium as well as the adjacent stroma through each estrous cycle, and at menopause when hormonal levels change, the gland involutes. The mammary gland is prone to develop epithelial cancer, and risk factors include early menarche and late menopause and late first pregnancy, which suggest that developmental changes associated with cycling and pregnancy, are critical parameters of cancer susceptibility. Normal as well as cancerous tissue development relies on proliferation of somatic stem cells, progenitors and differentiated progeny. In recent years, much effort has been invested in describing a cellular hierarchy in the mammary gland. In this endeavor, the mouse mammary gland is a widely employed model, and results obtained in mouse often are extrapolated to human tissue. There are, however, several prominent discrepancies between mouse and human mammary gland development, which in our opinion may hamper further progress in the field.

In this review, we first briefly describe mammary gland development and then emphasize on current knowledge about mouse mammary stem cells. We next turn to studies of the human breast epithelial stem cells, many of which - in lack of more appropriate models - include the mouse gland microenvironment as the model of choice. Finally, we discuss how differences in development and tissue composition between the mouse and the human gland may hinder a full understanding of the identity and functional characteristics of mammary stem cells with a view to highlighting some of the major obstacles to be tackled.

Abbreviations used in this paper: ACK, cytokeratin; DLLC, differentiated large light cell; ER, estrogen receptor; ECM, extracellular matrix; LDC, large dark cell; LRC, label-retaining cell; MRU, mammary repopulating unit; PI-MEC, parityinduced mammary epithelial cell; PR, progesterone receptor; SLC, small light cell; SP, side population; TDLU, terminal duct lobular unit; ULLC, undifferentiated large light cell.

*Address correspondence to: Lone Rønnov-Jessen. Cell and Developmental Biology, Department of Biology, the August Krogh building, University of Copenhagen, DK-2100 Copenhagen Ø, Denmark.Tel: +45.3532.1644. e-mail: Ironnov-jessen@ bio.ku.dk

Final, author-corrected PDF published online: 29 November 2011

ISSN: Online 1696-3547, Print 0214-6282

(๑) 2011 UBC Press

Printed in Spain 


\section{Mammary gland development}

The mammary gland develops during three distinct phases; embryonic, pubertal and pregnancy/lactation with the most drastic changes taking place postnatally. In the embryo, human and mouse gland development is very similar, although human gland development is somewhat more complex and has been detailed into ten stages according to the length of the embryo/fetus (Russo and Russo, 2004). In both species, however, the gland develops from the mammary placodes by invasion of a mammary epithelial bud into the underlying mesenchyme. The parenchyma then further sprouts and leads to the formation of a rudimentary epithelial structure embedded in the mesenchyme, which in the mouse is composed of adipose tissue, the mammary fat pad. A number of different signalling pathways have been identified as responsible for this process (reviewed by (Watson and Khaled, 2008)). This development leads to the establishment of five pairs of mammary glands in the mouse, located just below the skin between the fore- and hind limbs, and one pair of mammary glands in humans. In the human gland primordium, most of the epithelial cells stain for both luminal and basal markers, i. e. cytokeratin (CK) 19 and CK14. Such double-positive cells are not found during development of the mouse gland, in which at E15.5 and in less developed mammary glands, only CK14 is expressed (Sun et al., 2010). The cords of human mammary epithelium become fully canalized near term, and by the neonatal stage, the luminal and basal epithelial lineages are clearly separated and are easily identified as either CK19+ cells or CK14+ cells (recently reviewed by (Petersen and Polyak, 2010)). Further development takes place at puberty. In the mouse, puberty begins at week 3 , and is characterized by an increase in ovarian-derived estrogen. In the mouse, terminal end buds (TEBs) located at the tip of the rudimentary ducts are composed of an outer layer of cap cells and a multilayer of inner body cells. The cap cells are highly proliferative and eventually give rise to the ductal myoepithelial cells while the body cells are luminal epithelial precursors. The TEBs start invading the fat pad resulting in extensive elongation of ducts as well as secondary branching by a process called bifurcation (reviewed by (Silberstein, 2001)). Branching morphogenesis is a complex process regulated by numerous factors, both epithelial- and stroma-derived. One of the most important components is expression of estrogen receptor alpha $(E R \alpha)$ in the epithelium since its knockout causes the disappearance of TEBs so that the ducts cannot invade the fat pad (Mallepell et al., 2006). When the mouse reaches around 10-12 weeks of age, the ductal tree has reached the end of the fat pad and the TEBs regress. The epithelium now consists of two main cell types; an inner layer of luminal epithelial cells, which produce the milk during lactation, and an outer layer of myoepithelial cells resting on a basement membrane, which are responsible for pushing the milk through the ductal network to the nipple. After puberty, the ductal tree only fills a small part of the fat pad leaving large spaces between the ducts and ductules allowing lobuloalveolar development to take place at gestation (reviewed by (Silberstein, 2001)). Ductal growth is a strong intrinsic property of the mammary epithelium since early studies have shown that transplantation of any ductal fragment into a epithelium-cleared fat pad will result in the formation of an entire new ductal tree reaching the borders of the fat pad (Daniel et al., 1968). This also indicates that some kind of inhibitory signal prevents the ductal tree to grow beyond the fat pad boundaries as well as filling the space between the ducts. In this respect, transforming growth factor-betas, TGF $\beta$ s, are believed to be important regulators of ductal growth (reviewed by (Silberstein, 2001)). Mammary gland development in humans expands over several years (Russo and Russo, 2004). Like in the mouse, puberty in humans is characterized by extensive growth and further development of the female gland under the control of systemic hormones to compose a branching ductal system and associated lobules/terminal ductal lobular units (TDLUs), which are the functional units of the breast. Puberty probably represents the largest expansion of the stem cell compartment in a woman's life. The formation of lobules in the female human gland during puberty contrasts mouse gland development, where lobules first appear only if pregnancy occurs (reviewed by (Silberstein, 2001)).

During pregnancy in the mouse mammary gland, full development of the gland is reached by the formation of tertiary branches, which terminate in alveolar buds where milk-production is turned on at late pregnancy and during lactation (reviewed by (Silberstein, 2001)). This developmental process is under the control of the hormone progesterone, which is responsible for stimulating further side branching and alveolar formation. In addition, together with prolactin, progesterone induces differentiation of the alveoli as milk-secreting units. If the progesterone receptor (PR) is knocked out, alveologenesis and differentiation are disrupted (Brisken et al., 1998). Similarly, the transcription factor Gata3 is also necessary for the gland to reach full alveolar maturation since its conditional deletion perturbs alveolar differentiation and lactogenesis (KourosMehr etal., 2006). Following weaning, massive cell death results in post-lactational regression of the gland, a process termed involution, leaving the gland in a more or less pre-pregnant state albeit with the presence of a few alveoli throughout the gland (reviewed by (Richert et al., 2000)).

The human female gland undergoes comparable dramatic changes during pregnancy, but very importantly, lobules are already present prior to pregnancy and the human gland is generally not considered to be fully developed and differentiated until the end of the first full term pregnancy (Russo and Russo, 1987). During lactation there is little cell proliferation and in the absence of breastfeeding or after weaning, the gland involutes to morphologically resemble the pre-pregnancy gland. With each pregnancy these changes are repeated, and this regenerative capability is thought to rely on the presence of stem cells. The gland does not, however, return completely to the preparous state as the parous human gland subsequently has larger lobules. As a result, the parous organ contains more glandular tissue than if pregnancy had never occurred ((Russo and Russo, 2004) and references herein). Stem cells in the normal mammary gland thus are particularly proliferative and active during phases of embryonic/fetal development, puberty, and pregnancy, but are probably also involved in the more limited expansion during each estrous cycle.

\section{Mouse mammary stem cells}

Evidence for the existence of stem cells in the mouse mammary gland has accumulated over the last decades and it is now widely appreciated that a variety of different cell subpopulations exist, ranging from undifferentiated stem cells to terminally differentiated luminal epithelial and myoepithelial cells. The pioneering work of Daniel and DeOme half a century ago showed that when mammary 
epithelial tissue fragments were transplanted into epithelium-free mammary fat pads (cleared fat pads) they give rise to a functional ductal tree that resembles and behaves exactly like the normal mammary tree except that it is not connected to the nipple. Any tissue fragment would perform in this assay irrespective of the temporal or spatial origin, indicating that a candidate stem cell population was located along the entire ductal tree (Daniel et al., 1971; DeOme et al., 1959), but it also could be interpreted to suggest that the entire fat pad rather than specific topographic areas serve as the stem cell niche. Moreover, the transplanted outgrowths could be serially transplanted into new cleared fat pads up to 5-8 times before they would senescence, independent of the donor's age or reproductive history (Daniel et al., 1968; Daniel et al., 1971). These data have led to speculations that the mammary stem cell is a relatively dormant cell that only gets activated during gland development while the massive growth observed during pregnancy is probably supported by ductal and alveolar progenitors (reviewed by (Smith and Medina, 2008)) which may exhibit stem-like properties by being self duplicating and long-lived (Van Keymeulen et al., 2011). When the same type of experiment was performed with preneoplastic or neoplastic cells, the outgrowths could be serially transplanted inevitably (Daniel et al., 1975). The reason for this difference is still not known (reviewed by (Smith and Medina, 2008)). The cleared fat pad assay now has become the golden standard to investigate the repopulating properties of the cells of interest. The fact that it is possible to transplant mouse mammary cells into their normal microenvironment and assess their stem cell-like or tumorigenic properties highlights the uniqueness of this organ. In the following section the experimental evidence for the existence and characterization of mouse mammary stem cells will be outlined.

\section{In situ observations of the mouse mammary stem cell}

Electron- and light-microscopic analyses have shown that the mouse mammary epithelium is composed of a heterogeneous population of cells with distinct cellular structures, localization and renewal capacity, which may in turn reflect different stages of epithelial differentiation (Chepko and Smith, 1997; Smith and Medina, 1988). Four types of epithelial cells can be defined by ultrastructural examination; primitive small light cells (SLC), undifferentiated large light cells (ULLC), differentiated large light cells (DLLC) and large dark cells (LDC). The LDC correspond to differentiated luminal and myoepithelial cells while the SLC have been described as a having stem cell-like features based on the presence of mitotic chromosomes, lack of any specialized organelles and the ability to undergo symmetric and asymmetric division (reviewed in (Smith and Chepko, 2001)). In addition, the SLCs have a basal location, sometimes reaching the basement membrane but never the lumen (Chepko and Smith, 1997). The percentage of SLCs is constant at $3 \%$ from the virgin gland through pregnancy and involution, suggesting that the relative number of SLCs increase and decrease in proportion to the more differentiated cells. Interestingly, the SLCs disappear in serial transplants that have reached growth senescence, indicating that these cells are necessary to support the observed repopulating properties of mammary epithelial cells (reviewed by (Smith et al., 2002)). Based on the morphological and temporal characterization of SLCs, these cells most likely are mouse mammary stem cells. Furthermore, the ultrastructural descriptions have revealed that the mammary stem cell is situated in a specialized microenvironment, the stem cell niche, which plays a pivotal role in fate determination. Unfortunately, it is not possible to correlate the phenotypical properties of the SLCs to candidate stem cell population isolated from fresh tissue, meaning that the ultimate proof of their stem cell properties cannot be tested in the repopulating transplantation assay. Nonetheless, the fact that the SLCs have a suprabasal position (Chepko and Smith, 1997) fits very nicely with the prospective isolation of mouse mammary stem cells from the basal layer, as described below.

\section{Functional characterization of mouse mammary stem cells}

Characterization of the mouse mammary stem cell in cell culture has not been as extensive as for their human counterpart due to the obvious advantage of the in vivo repopulating assay, which is highly reproducible across the scientific field. Also, when cultured, sorted mouse mammary epithelial cells are very plastic with regard to marker expression (Alvi et al., 2003; Smalley et al., 1998), making them a less ideal experimental model for mouse mammary stem cell studies as compared to the repopulating assay. However, the strength of culture experiments is that it - at least ideally - is a controllable system in which each influential factor can be strictly regulated, while in the in vivo setting the exact circuit of events is not known.

Since the first experimental evidence for the existence of mammary stem cells, much effort has been focused on the identification and functional characterization of these cells. From transplantation experiments of mammary epithelial cells into cleared fat pads it has become clear that a hierarchy of different stem cells exist; some are limited to making lobular structures, others in making ductal structures and finally stem cells that are able to give rise to both structures and generate a fully functional mammary tree (Smith, 1996). The exact nature of each subpopulation is still not known. The lobule-limited cells are unable to produce cap cells so that invading TEBs are not formed while ductal-limited cells do not give rise to alveolar structures during pregnancy (reviewed by (Smith and Medina, 2008)). Both cell populations give rise to structures that are composed of an inner layer of luminal epithelial cells and an outer layer of myoepithelial cells indicating that they are derived from a single pluripotent precursor (Kordon and Smith, 1998). Recent studies with WAP-Cre/Rosa-lacZ transgenic mice have shown that the lobular-limited stem cells become functionally active during pregnancy under the influence of estrogen and progesterone and that they are located in the terminal ducts where they give rise to alveolar structures (Wagner et al., 2002). Interestingly, subsequent transplantations of these cells into cleared mammary fat pads together with wild-type epithelial cells revealed that they were multipotent and self-renewable, giving rise to both ducts and alveoli composed of luminal epithelial and myoepithelial cells (Boulanger et al., 2005; Matulka et al., 2007). However, their main function is probably to give rise to new alveoli during pregnancy, since they do not show self-renewal ability when transplanted into cleared fat pads on their own (Boulanger et al., 2005). These cells have been termed parity-induced mammary epithelial cells (PI-MEC) since their multipotent properties are first revealed following pregnancy. In view of the fact that these cells are relatively abundant in parous female mice it is unlikely that they represent a homogenous population of stem cells. Instead, it has been proposed that in addition to stem cells the population includes cells that are essential for the stem cell niche (Matulka et al., 2007). 
To approach the identity of mouse mammary stem cells, longterm BrdU labelling to reveal label-retaining cells (LRC) has been employed (Welm et al., 2002). Label-retaining cells are believed to be slowly cycling cells that retain their original labelled DNA template strand and hence can be identified in the tissue weeks after administration of the DNA-labelling dye by means of their fluorescent nuclei. That LRCs are candidate stem cells has been shown in a number of other tissues, including hair follicles, muscle and intestine (Blanpain et al., 2004; Morris and Potten, 1999; Potten et al., 1997; Shinin et al., 2006). LRCs in the mouse gland are enriched for the surrogate stem cell marker Sca-1 and can regenerate an epithelial outgrowth when transplanted in cleared mammary fat pads as opposed to the Sca- $1^{\text {neg }}$ cells (Welm et al., 2002). Furthermore, the LRCs were able to efflux the DNA-dye Hoechst-33342, referred to as the "side population (SP)", and also showed repopulating properties, which was later supported by others (Alvi et al., 2003). However, since then, others have failed to reproduce the data on stem cell properties of mammary SP-cells (Matulka et al., 2007; Stingl et al., 2006), emphasizing that the exact nature of these cells still remains unclear. Others have, however, further pursued the stem cell properties of LRCs, and have somewhat surprisingly revealed that a large part of the LRCs, including the PI-MECs, are actively dividing asymmetrically so that they keep their template labelled DNA strand upon division (Smith, 2005). Therefore, the presence of a LRCs cell in the mammary gland many weeks after the administration of the DNA-dye does not necessarily indicate that the cells are not cycling. That mammary stem cells may be cycling has also been suggested by others (Stingl et al., 2006). Of note, these experiments were all performed during active ductal growth in early life, a stage where stem cells are expected to be dividing. Interestingly, a proportion of the LRCs express the steroid receptors, ER $\alpha$ and PR, indicating that LRCs represent a hierarchy of different stem cells and progenitor cells (Booth and Smith, 2006). During pregnancy and accompanied alveologenesis, the LRCs continue to cycle and the expression of steroid receptors changes in these cells (Booth et al., 2008). A small proportion of the LRCs, called "undefined cycling cells", is negative for cytokeratins, steroid receptors as well as myoepithelial markers and is located basally throughout the ductal tree (Booth et al., 2008). It remains to be established whether these cells correspond to the mammary repopulating unit cells (MRUs), that are enriched for by flow cytometry based on the expression of CD24, CD29 ( $\beta 1$-integrin) and CD49f ( $\alpha 6$-integrin) (Shackleton et al., 2006; Sleeman et al., 2006; Stingl et al., 2006), which have also been shown to lack expression of steroid receptors (Asselin-Labat et al., 2006; Sleeman et al., 2007).

In the last few years, techniques for retrieval of viable cells from freshly dissociated mammary tissue have significantly improved. This has permitted investigation of the surface marker expression of mammary epithelial cells and thereafter sorting of the cells of interest in a flow cytometer. In this way, three separate research groups elegantly showed that when different cell subpopulations were sorted out based on the expression of CD24, CD29 or CD49f, mouse mammary stem cells could be highly enriched for, as evaluated by the repopulation assay in cleared mammary fat pads, even at relatively low numbers of transplanted cells (Shackleton et al., 2006; Sleeman et al., 2006; Stingl et al., 2006). More specifically, three distinct cell populations could be identified when mouse mammary cells were analyzed for expression of CD24, namely
CD24 $4^{\text {neg }}$ cells (non-epithelial), CD24 low cells (myoepithelial) and CD24 high cells (luminal epithelial) (Sleeman et al., 2006). When transplanted into cleared mammary fat pads, the CD24 ${ }^{\text {low }}$ cells have the highest repopulating ability, generating outgrowths that fill the whole mammary fat pad, even when as few as 1,000 cells were transplanted. The outgrowths were composed of both luminal epithelial and myoepithelial cells, which were organized in a correct manner, reflecting the multipotency of the CD24 ${ }^{\text {low }}$ cells. The CD$24^{\text {high }}$ cells also showed regenerative potential but at much higher cell numbers and they were not capable of generating structures that filled the whole fat pad. The structures did, however, contain both luminal epithelial and myoepithelial cells, indicating the multipotency of the transplanted cells. It remained to be explored whether the transplanted outgrowths were able to undergo full differentiation during pregnancy and lactation or whether they exhibited self-renewal upon serial transplantation, which is a critical property of stem cells. These aspects were, however, included by others (Shackleton et al., 2006; Stingl et al., 2006), who enriched for mammary-repopulating unit cells (MRUs) by high expression of CD29 or CD49f and medium expression of CD24, respectively. The frequency of MRUs in the CD29 ${ }^{\text {hi }} \mathrm{CD} 24^{+}$and CD24 ${ }^{\text {med }}$ CD49f high populations was around $1 / 60(1.67 \%)$ as compared to $1 / 1,400-$ 4,900 for the total population of mammary epithelial cells. Upon transplantation, the sorted cells can generate a fully functional ductal tree that is able to undergo lobulo-alveologenesis during pregnancy and lactation resulting in milk-production (Shackleton et al., 2006). Impressively, the authors managed to generate ductal outgrowths after transplantation of a single MRU cell, although at a low success rate (Shackleton et al., 2006; Stingl et al., 2006). When the MRU subpopulation is analyzed for lineage marker expression it expresses basal/myoepithelial markers, suggesting that the MRUs are normally located in the basal layer of the ductal tree. It is clear though, that the majority of the cells sorted when enriching for MRU cells are not candidate stem cells since the they comprise only around $1.67 \%$ of the sorted cells with the rest of the cells representing a mixture of progenitors and differentiated cells (Shackleton et al., 2006; Stingl et al., 2006). In contrary to previous reports (Alvi et al., 2003; Welm et al., 2002), the MRU cells within the $\mathrm{CD}_{29}{ }^{\text {hi }} \mathrm{CD} 24^{+}$and $\mathrm{CD} 24^{\mathrm{med}} \mathrm{CD} 49{ }^{\text {high }}$ subpopulations did not show a SP-phenotype, nor did they express Sca-1. The PI-MECs have subsequently been shown to belong to the CD49fhi population (Matulka et al., 2007). However, the PI-MECs lie mainly in a luminal epithelial niche (Wagner et al., 2002), which is in contrast to the reports published on the MRUs. These findings imply that PI-MECs and MRUs may represent distinct cell subpopulations, albeit both with stem cell properties. The importance of expression of CD29 in the basal layer, which includes the MRUs, is revealed by the lack of generation of secondary outgrowth from CD29-deleted primary tissue fragments (Taddei et al., 2008), highlighting that intact cell-extracellular matrix (ECM) interactions, mediated by CD29, are needed for stem cell maintenance. The primary outgrowths still show ductal growth and alveologenesis during pregnancy, but is delayed when compared to control mice. This delayed alveologenesis late in pregnancy was postulated to be mediated by a population of activated alveolar progenitors, that were not able to give rise to ductal structures and that are not affected by the lack of CD29 expression (Taddei et al., 2008). These cells clearly show similarity to the PI-MECs. This again highlights that the mammary epithelium is composed of a variety 
of different stem cells and progenitors, each with distinct roles, but which collectively maintain a functional mammary gland. It is still unknown how different cells in the hierarchy contribute to normal tissue homeostasis and gestation.

Even though the luminal epithelial lineage shows low regenerative potential (Sleeman et al., 2006; Sleeman et al., 2007) or none at all (Shackleton et al., 2006; Stingl et al., 2006) when transplanted in the cleared mammary fat pads at low cell number, studies have shown that they are a heterogeneous group of different subpopulations, including progenitors, which play a pivotal role during normal homeostasis and at gestation. Furthermore, although the most primitive stem cell may be found within the basal compartment, recent studies have shown evidence for the luminal progenitors as the cell of origin for breast cancer (Lim et al., 2009; Molyneux et al., 2010), as was originally postulated decades ago. Clearly, the luminal epithelial compartment contains cells that can differentiate to both luminal epithelial and myoepithelial cells, as revealed by labelling studies (Boulanger et al., 2005; Matulka et al., 2007; Molyneux et al., 2010). Luminal epithelial progenitors are characterized by the expression of CD61 ( $\beta 3$-integrin) (AsselinLabat et al., 2007) and low expression of Prominin-1 (CD133) and Sca-1 and lack of steroid receptors (Sleeman et al., 2007). Importantly, although the regenerative potential of the luminal epithelial progenitors is low, they still can generate outgrowths that are composed of both luminal epithelial and myoepithelial cells, indicative of multipotency (Sleeman et al., 2007). Further, is has been shown that the regenerative potential of luminal cells can be greatly enhanced when co-injected with reconstituted extracellular matrix, MatrigelR (Vaillant et al., 2011). However, no secondary outgrowths arise from these luminal-derived primary outgrowths when retransplanted into cleared fat pads, indicating that the cells are not able to self-renew (Vaillant et al., 2011).

\section{Identification and functional characterization of stem cells in the human mammary gland}

Evidence that human normal mammary epithelium develops from a common cellular origin, in casu stem cells, was first provided by studies of $\mathrm{X}$-chromosome inactivation pattern. Microdissection of adult normal mammary epithelium followed by analysis of the methylation pattern of DNA demonstrated that the normal human breast is organized into discrete regions in which all cells have the same X-chromosome inactivated (Tsai et al., 1996) and thus are derived from the same cellular origin. As stated above though, long before this finding, it was demonstrated that implantation of normal tissue into mouse cleared fat pad produces branching and thus comprise the capacity to regenerate the mammary tree (DeOme et al., 1959). To directly identify human mammary stem cells, unravel their developmental hierarchy or determine their regulation have, however, not been easy tasks and still are the subjects of intense research. The perhaps most obvious approach for studying the function and dynamics of stem cells in human breast is to use primary tissue. In comparison to studies in the mouse, however, relatively few studies have addressed the identity of the stem cell and its differentiation hierarchy in the human normal mammary gland. This is probably due partly to limited access to biopsy material, which in most cases is obtained from reduction mammoplasty in adults, partly to the fact that sporadically collected human material may exhibit a higher degree of biological variation than material obtained from inbred mouse strains, in turn requiring even more samples to reach statistical significance in each experiment.

While methods such as histological staining of normal breast tissue provide a snapshot of the cells in question, additional methods of tissue analysis are indeed required to unravel developmental dynamics. One such approach is to incubate pieces of human breast tissue in immune-compromised mice. By subcutaneous implantation and DNA radiolabelling of small pieces of normal breast tissue into athymic nude mice to which $17 \beta$-estradiol was administered, a population of label-retaining (long lived) cells can be identified and analyzed (Clarke et al., 2005). This population includes cells expressing ER and the putative stem cell markers CK19, p21 ${ }^{\mathrm{CIP} 1}$ and Msi-1. However, while both p21 ${ }^{\mathrm{CIP} 1}$ and Msi1 expression are highly associated with the ER-positive subpopulation, they signify different subsets of cells (Clarke et al., 2005), thus perhaps identifying progenitors rather than stem cells, and at the same time demonstrating that methods to prospectively isolate stem cells and analyzing their development in culture and/or in situ are needed. As for the mouse, this is in part accomplished by isolation and study of specific cell populations by use of flow cytometry.

As in the mouse, side population cells have been identified in the human breast gland (Alvi et al., 2003; Zhou et al., 2001). The side population results from action of $A B C$ transporter cassette proteins and in particular breast cancer resistance protein 1/ABCG2 (Zhou et al., 2001). When applied in the above mentioned study by Clarke et al., (Clarke et al., 2005), it turned out that the side population in human breast indeed is enriched for ER-positive cells, but belongs to neither the luminal nor the myoepithelial differentiated cell lineages as markers for these cells, MUC1 and CALLA, respectively, were not expressed (Clarke et al., 2005). The side population was in contrast to other cells, however, able to form branching structures in three-dimensional Matrigel (Clarke et al., 2005), an assay originally established to recapitulate in situ differentiation of isolated cells (Petersen et al., 1992). Histological stainings further suggest that human breast stem cells have an intermediate or suprabasal position in the epithelium (Clarke et al., 2005; Gudjonsson et al., 2002; Stingl et al., 2001), and in the adult breast such bipotent $\mathrm{CK} 19^{+} / \mathrm{CK} 14^{+}$progenitors have been shown to be able to differentiate into lineage-restricted luminal and myoepithelial cells (Gudjonsson et al., 2002). While such double-positive epithelial cells are not present during early gland development in the mouse, they are found at puberty, 2-3 weeks after birth, where CK14 is detected among suprabasal/luminal cells (Sun et al., 2010). Whether these cells are also bipotent remains to be investigated.

Human mammary stem cells have also been sought for by combining flow cytometry and in vitro colony assays with markers to identify progenitors and differentiated cells, respectively. Primary human breast epithelial cells cultured on fibroblast feeder layers give rise to three morphologically distinct types of colonies, one expressing luminal markers EpCAM, $\alpha 6$ integrin and MUC1, one expressing the myoepithelial marker CK14, and one type exhibiting a mixture of phenotypes with a central core of cells expressing CK19, EpCAM and variable levels of MUC1 surrounded by CK14 ${ }^{+}$ cells (Stingl et al., 2001). With passage, however, the frequencies of the three colony types are skewed towards myoepithelial differentiation (constituting 19\% of the colonies in primary culture and $97 \%$ of the colonies in third passage) (Stingl et al., 2001), which shows that the culture conditions (including 5\% serum and 
epidermal growth factor) probably support myoepithelial propagation at the expense of other cell types. To confirm that colonies with mixed phenotype indeed represent clones, and thus possibly stem cells, EpCAM ${ }^{+}$cells were single cell sorted and the resultant colonies were shown to contain a central core of $\mathrm{MUC1}{ }^{+}$surrounded by $\mathrm{CK} 14^{+}$cells (Stingl et al., 2001). These findings again are in accordance with the existence of suprabasal cells in situ with low MUC1-expression and high EpCAM/ESA- expression with stem cell-properties (Gudjonsson et al., 2002).

Other clues as to the identity of normal breast stem cells have come from studies of tumors which may be considered caricatures of normal development. Most breast tumors display luminal cell differentiation in terms of CK19 and ER expression. It has further been demonstrated that lin $/ C D 44^{+} / C D 24^{\text {low/ }}$ cells from pleural effusions of breast cancer patients are more tumorigenic in immunecompromised mice than CD44/CD24+ cells and moreover that lin $/$ CD44 ${ }^{+}$CD24 low/- cells phenocopy the original tumors, thus suggesting that lin $/ \mathrm{CD} 44^{+} / \mathrm{CD} 24^{\mathrm{low} /}$ cells are breast cancer stem cells (Al-Hajj et al., 2003), while CD24+ cells represent their progeny. The molecular profiles of these two CD44+ and CD24+ populations in tumors have subsequently been analyzed and compared with $\mathrm{CD}_{4}{ }^{+}$and $\mathrm{CD} 24^{+}$cells isolated from normal breast (Shipitsin et al., 2007). Upon substitution of CD44 with a CD44+ cell-specific gene, PROCR, a nearly mutually exclusive expression pattern of known luminal epithelial and stem-cell markers is observed in CD24+ and PROCR/CD44+ populations, and hierarchical clustering of SAGE libraries very importantly demonstrated that normal and cancer PROCR/CD44 ${ }^{+}$cells are more similar than PROCR/CD44 ${ }^{+}$ cells and $\mathrm{CD}_{24}{ }^{+}$cells isolated from the same tissue (Shipitsin et al., 2007). In contrast to earlier studies, however, in which the ER+ cells were contained within the side population of stem cells (Clarke et al., 2005), there was a low abundance of ER in PROCR/CD44+ cells from normal breast (Shipitsin et al., 2007).

Other studies have applied culture models to reveal self-renewal and differentiation capacity of isolated cell populations in the search for human breast epithelial stem cells. An assay of clonal spherical growth of neural cells in nonadherent culture into so called neurospheres (Reynolds and Weiss, 1996) has been adapted to breast epithelial cells (Dontu et al., 2003). Mammospheres can form from primary epithelial cells at a density of 20,000 cells per well, and these can be serially passaged for up to 5 passages with a mammosphere-forming frequency of 4 out of 1,000 cells. The mammosphere-initiating cells are contained in the side population and gene expression analysis of mammospheres as compared to cells grown in differentiating conditions show that mammospheres express candidate markers for stem and progenitor cells (Dontu et al., 2003). Others have subsequently shown that the mammosphere side population has a CD24low/CD44 low phenotype, but that these cells cannot form mammospheres. Instead, the mammosphereinitiating capacity is in the CD44 ${ }^{\text {high}} /$ CD2 $4^{\text {low }}$ population (Dey et al., 2009) in accordance with earlier suggestions that normal breast stem cells display this phenotype (Shipitsin et al., 2007).

At present it is not clear to which extent $\mathrm{MUC1} 1^{+/ /} / \mathrm{EpCAM}^{+} / \mathrm{CK}_{19}{ }^{+}$ progenitors (Stingl et al., 2001) overlap with CD44 ${ }^{+}$CD24- stem cells (Shipitsin et al., 2007), and both marker combinations define a subset of cells present at a higher frequency than expected for a stem cell population in adult tissue. Thus, a specific marker or rather a more specific marker combination to identify normal human breast stem cells is highly warranted.
While mammary stem cells may belong to the basal or suprabasal compartment, it remains an unresolved question whether these cells play any role in the development of breast cancer. In this respect most information has been gathered from BRCA mutation-associated breast cancers and BRCA1 deficient mice (Lim et al., 2009; Molyneux et al., 2010). Interestingly, the expanded cellular compartment in BRCA carriers as defined by flow cytometry with EpCAM and CD49f was similar to the compartment previously identified as enriched for multipotent progenitors by three-dimensional Matrigel culture conditions (Lim et al., 2009; Villadsen et al., 2007). Likewise, a CK14/CK19 double positive compartment previously suggested to be stem-like (Villadsen et al., 2007) was also expanded in haploinsufficient BRCA1 human breast tissue (Proia et al., 2011). Thus, until a clear association is established between the mammary stem cell compartment and breast cancer it seems as if the luminal progenitor compartment represents the best candidate for a cell of origin at least for basallike breast cancer.

\section{The mammary stem cell niche}

A stem cell niche is defined as the microenvironment (neighbouring signalling cells, both epithelial and stromal, and ECM components) surrounding an undifferentiated stem cell, which provides the necessary signals to maintain stem cell-specific characters, including self-renewal, quiescence and immature nature (reviewed by (Fuchs et al., 2004)). The exact nature and location of the stem cell niche in the mammary gland has not been fully defined, although the ducts have been suggested as a candidate location (Fernandez-Gonzalez et al., 2009; Villadsen et al., 2007). As stated above, mammary epithelial fragments taken from any area of the gland can give rise to new ductal trees indicating that stem cells and their niches are distributed throughout the ductal network (Daniel et al., 1971; DeOme et al., 1959), or alternatively, that the entire fat pad is in fact the niche. This would explain why transplantation of a single MRU cell into the cleared fat pad results in an elaborate epithelial outgrowth (Shackleton et al., 2006; Stingl et al., 2006). At the same time it underscores the importance of stroma-derived signals needed to support the mammary stem cell. The exact nature of these stroma-derived signals, positive as well as negative, is, however, still not elucidated. It is clear though that these signals must direct both symmetrical and asymmetrical division of the stem cells as well as probably co-develop the surrounding stroma in order for a fully functional ductal tree to arise.

So far, the specific signalling pathways involved in establishment, maintenance and activation of the stem cell niche remain elusive. It is beyond doubt though that the steroid hormones play a pivotal role in directing the fate of the stem cell, probably by acting on the stem cell niche cells. Although mouse mammary stem cells themselves do not express steroid receptors (Asselin-Labat et al., 2006; Sleeman et al., 2007), ductal and alveolar growth is severely inhibited in ER knockout mice (Mallepell et al., 2006). Thus, upon knockout of $E R \alpha$, a normal rudimentary ductal system is formed but the subsequent ductal growth during puberty is blocked. This block can, however, be overcome by generating chimaeric epithelial structures including a mixture of wild-type and ER $\alpha$ knockout epithelial cells (Mallepell et al., 2006). This indicates that the knockout cells do contain a stem cell population, but in the absence of the necessary signals from ER $\alpha$ positive cells, their stem cell proper- 
ties are not supported. One example of a crucial paracrine factor provided by ER $\alpha$ positive cells is amphiregulin, which is secreted in response to estrogen stimulation (Ciarloni et al., 2007). Amphiregulin in turn acts on the stromal cells to start a signalling cascade, which has yet to be fully understood, but this crosstalk eventually leads to stem cell proliferation and ductal elongation (Wiesen et al., 1999). During pregnancy, progesterone takes over the role as the prime stimulator of alveologenesis. Progesterone induces the secretion of RANK ligand (RANKL) and wnt-4, which in turn act on the mammary stem cell to stimulate expansion (Brisken et al., 2000; Mulac-Jericevic et al., 2003). Interestingly, RANKLis secreted by the luminal lineage while the RANK receptor is expressed by the mammary stem cell population (Asselin-Labat et al., 2010) in turn implicating luminal epithelial cells as part of the stem cell niche. In summary, a scenario arises in the mouse gland where at puberty the stem cell niche is under the control of estrogen while at pregnancy it is under the control of progesterone. It remains to be revealed whether these two niches involve the same stem cells and niche cells or whether the cellular composition of the niche changes during mammary gland development.

While still debating the exact identity and localization of the mammary stem cell, already the next question arises as to whether stem cell characteristics such as the capacity for self-renewal and differentiation as demonstrated in culture models and by transplantation to the mouse in fact represents correct replicas of the in vivo situation. This question may be particularly pertinent to the human mammary stem cells. Whereas in mice, the ultimate evidence for the existence of stem cells is the clonal repopulating ability and morphogenic capacity within the cleared fat pad, i. e. within the original niche (Shackleton et al., 2006; Stingl et al., 2006), such experiments cannot be performed in humans, and therefore have had to rely on surrogate assays (Clarke et al., 2005; Dontu et al., 2003; Gudjonsson et al., 2002; Stingl et al., 2001). Likewise, as specific mammary stem cell markers are not available, postulated surrogate stem cell markers are employed (Villadsen et al., 2007). Three surrogate stem cell markers, SSEA-4, CK15 and CK6a, localize focally to discrete clusters of cells in ducts, including terminal ducts, and are essentially absent from lobules. In accordance with the fact that quiescence is a general property of stem cells in their niche, putative stem cells residing in ducts are essentially quiescent, whereas the progenitor cells in the lobules are more likely to be actively dividing. By collecting collagenase-released ducts and lobules under the microscope and analyzing the derived cells by colony formation in culture, mammosphere formation, and morphogenesis in Matrigel, it was suggested that stem cells indeed reside in ducts rather than lobules. Histological stainings further showed that the candidate stem cell zone in ducts is enriched in cells identified as being SSEA $-4^{\mathrm{h}} / \mathrm{CK}^{+} / \mathrm{CK} \mathrm{a}^{+} / \mathrm{CK} 15^{+} / \mathrm{Bcl}-2^{+}$cells, which are generally quiescent and surrounded by chondroitin sulfate. Moreover, staining for the lineage markers CK14 and CK19 further revealed multipotent cells in the stem cell zone and three lineage-restricted cell types outside this zone (Villadsen et al., 2007). On their own, each of these experimental approaches are not adequate for pin pointing the stem cell niche, but when collectively applied, they have led to the identification of a putative stem cell zone in human breast.

Being somewhat far from tracking down the actual human mammary stem cell niche, it may be no surprise that the signalling pathways responsible for self-renewal capacity are also relatively poorly described. Some clues, however, have come from molecular profiling of isolated cells. While BM1 expression is more or less the same in the $\mathrm{CD}_{4} 4^{+}$and $\mathrm{CD} 24^{+}$populations, the hedgehog signalling pathways genes of transcription factors, Gli1 and Gli2 are highly expressed in CD44+ cells as compared to CD24+ cells (Shipitsin et al., 2007). This concurs with the findings that the expression levels of Gli1 and Gli2 are approximately 25 - fold and 6-fold higher in mammospheres than in differentiated epithelial cells cultured in monolayer (Liu et al., 2006). It could be argued, however, that the expression level in mammospheres should be compared with other non-adherent cells to exclude that 2-D versus 3-D culture in itself contributed to the difference rather than reflecting undifferentiated versus differentiated cells. Nevertheless, a lin $/ C D 44^{+} /$ CD24-1ow population isolated by flow cytometry from a metastatic human breast carcinoma xenografted in NOD-SCID mice also exhibits activated hedgehog signalling pathway, including a 30fold and 6-fold higher expression of Gli1 and Gli2, respectively (Liu et al., 2006).

In lack of information about normal cells, data from cancer progenitors or stem cells may be relevant. The TGF-beta signalling pathway apparently is important in CD44+ tumor cells. Specific activation of the TGF-beta signalling pathway is due to restricted expression of the TGF-beta receptor 2 in $\mathrm{CD} 44^{+}$cells and its silencing in $\mathrm{CD}_{24}{ }^{+}$cells. In accordance with this difference, treatment with a TGF-beta receptor kinase inhibitor specifically influences CD44+ cells and leads to a mesenchymal-epithelial transition (Shipitsin et al., 2007). Whether TGF-beta signalling is equally important in normal breast stem cells remains to be demonstrated. In general, however, TGF-beta signalling is important in epithelial-stromal interaction, and TGF-beta expression in the mouse gland mediates inhibition of ductal growth and reduction of lateral branching by TGF-beta through stromal receptors (reviewed by (Silberstein, 2001)), which in turn indeed emphasizes the importance of the microenvironment.

Other signalling pathways which may be important for the stem cell niche are those associated with the embryonic morphogen, Nodal also belonging to the TGF-beta superfamily and its coreceptor Cripto-1 (reviewed by (Strizzi et al., 2008)). Under normal conditions, the Nodal signalling pathway is strictly regulated at the transcriptional and post-translational levels as well as by extracelIular Nodal inhibitors such as Lefty, which antagonizes the Nodal signalling pathway by binding to and interacting with Nodal and/ or Cripto-1 (reviewed by (Strizzi et al., 2008)). That Nodal and Cripto-1 may regulate stem cell activity has been suggested by overexpression of Cripto- 1 in transgene mouse models leading to increased lateral side branching of the developing ducts (hyperplasia) (Wechselberger et al., 2005) and delayed lobuloalveolar development (Sun et al., 2005). Interestingly, in both models there was an increased incidence of mammary gland tumors (Sun et al., 2005; Wechselberger et al., 2005) which point to deregulation of the restricting signals from the microenvironment as possible causes of tumor development. Whether similar mechanisms apply to the human gland is currently not known, but Cripto-1 expression is prevalent in human solid tumors, including those of the breast (Kelly et al., 2011).

The Notch pathway acts as a regulator of cell survival and proliferation and is a juxtacrine cell-cell signalling mediator in that ligands expressed on the signalling cell bind to Notch receptors on the adjacent signal-receiving cell (reviewed by (Harrison et al., 
2010)). The vertebrate Notch 1 and Notch 4 homologs are involved in mammary gland development and Notch 4 in particular has been further investigated. Transgenic WAP/int3 mice expressing constitutively active Notch 4 display little lobular development and growth during late pregnancy between day 14 and parturition, and there is no secretory activity (Gallahan et al., 1996). During pregnancy, dysplastic lesions appear and they subsequently progress to carcinomas. Virgin as well as multiparous mice develop tumors, but the latency period is considerably shorter in parous mice. Again this points to delayed/diminished lobular development or gland differentiation as a "risk factor" of cancer development. Also, the normal function of Notch 4 may be to maintain mammary epithelial cells in a proliferatively responsive state, i. e. to support stem cell/progenitor capacity. This concurs with subsequent studies in human breast cells where Notch activating ligands increase secondary and tertiary mammosphere formation 10-fold as well as the size of primary and secondary mammospheres (Dontu et al., 2004), thus suggesting that Notch activation promotes selfrenewal in stem cells.

In summary, in terms of morphology, development is well described in both the mouse and human mammary gland. However, while a more integrated picture of participating stem cells and differentiated cell lineages has started to evolve, much remains to be understood about different stem cell populations, the mammary stem cell niches and the signalling pathways governing distinct phases of development. Below some of these unresolved issues and open questions are discussed.

\section{Discussion}

Whereas the original transplantation studies paved the way for studying mammary gland development, it is the rather advanced protocols for multiparameter sorting of mammary epithelial cells in combination with repopulation assays which have forwarded the research field within recent years. In particular, prospective isolation of different subsets of cells has allowed researchers to interrogate the stem cell hierarchy in the mammary gland. Also, the separation of distinct subpopulations has allowed for the gene expression profiling of individual subsets of cells to begin unravelling the signalling pathways that contribute to mammary gland homeostasis. The ultimate goal of these approaches is to fully understand mammary gland development and function and to gain insight into how breast cancer arises and develops. Indeed, very recent studies have demonstrated that hierarchy dissection (Lim et al., 2009; Molyneux et al., 2010) results in a better understanding of the cell of origin of breast cancer. However, in our opinion a number of important issues need to be taken into consideration when interpreting results obtained in the mouse and human gland, respectively, and in addition several problems need to be resolved.

Several profiles of putative stem cells or of populations including cells with stem cell properties have been suggested, but at present it is not entirely clear whether these actually portray identical cells. This is due in part to the fact that some of the markers, for instance Sca-1, is expressed in one of the species only (Sleeman et al., 2007; Welm et al., 2002), in part to the fact that most of the populations identified and isolated, for instance CD44 /CD24 cells (Shipitsin et al., 2007), occur at a higher frequency than would be expected for stem cells in adult tissue. Even for well established breast cell markers such as steroid receptors unresolved issues persist. While mouse mammary stem cells do not express ER, it is still a matter of debate whether human breast stem cells do. Moreover, as studies of human cells rely mostly on culture assays, it is of particular relevance that $\mathrm{ER}^{+}$cells are not easily maintained and propagated in culture.

The vast majority of mammary gland stem cell research is performed in mice. Obviously, this is due to an easier access to homogenous tissue material as compared to human tissue, the latter being highly influenced by the woman's age, behavioural habits and reproductive history. Another advantage of using the mouse model is that mouse gland tissue or cells can be transplanted into their physiologically relevant microenvironment, the cleared mammary fat pad. And perhaps most importantly, mice can be genetically manipulated and the technique is sophisticated to a level which allows the elucidation of the significance of, for instance, a specific transcription factor at the individual developmental stages of the gland. Nevertheless, caution must be taken not to directly extrapolate data from mice to humans. Although many similarities in development between the species exist, there are also important differences. One of the most obvious differences is that in humans, lobules are established already at puberty, while in the mouse lobular structures first develop during pregnancy. Furthermore, while the involuted mouse mammary gland structurally resembles the virgin gland with the presence of some alveoli (reviewed by (Richert et al., 2000)), the human gland has undergone significant morphological changes as a result of pregnancy and breastfeeding (reviewed by (Russo and Russo, 2004)). These structural differences between the mouse and human mammary gland have not been experimentally addressed in stem cell studies but in our opinion their impact on the characteristics of the mammary stem cell cannot be excluded. This might for instance mean that either different stem cell populations are called upon in the two species during puberty and pregnancy, respectively, or that the operative signalling circuits are not the same in mouse and man, or both. Even within the same species, the different developmental stages of the gland may employ different subsets of stem cells/progenitors. Thus, in most studies using sorted mouse mammary stem cells, the mice are between 8-12 weeks old, and as such at the end of puberty. Here, the stem cell function segregates with the basal lineage (Shackleton et al., 2006; Sleeman et al., 2006; Stingl et al., 2006). However, some TEBs might still be present at this stage, where cap cells, which give rise to ductal myoepithelial cells, have been proposed to serve as the stem cells responsible for pubertal ductal growth (Williams and Daniel, 1983). A contribution of cap cells to the enriched mammary stem cell population isolated by high expression of CD49f and CD29 cannot be entirely excluded, and it is still not known whether cap cells are equal to the stem cells in the adult mammary gland. In fact, a recent study shows that the actively dividing cap cells during puberty as well as the basal alveolar bud cells in pregnancy function as multipotent, self-renewable stem cells (Bai and Rohrschneider, 2010) and that they both correspond to the previously isolated MRU cells enriched for by high expression of CD29 and CD49f (Shackleton et al., 2006; Stingl et al., 2006). During pregnancy, another stem cell population appears, the PI-MECS, which has been shown to have luminal-like features (Wagner et al., 2002), which is distinct from the MRU cells isolated from the virgin gland (Shackleton et al., 2006; Sleeman et al., 2006; Stingl et al., 2006). Whether these two latter cell populations represent the same cells or separate 
stem cell entities remains to be determined.

Another significant difference between the human and mouse gland is the composition of the immediate epithelial microenvironment. Mouse epithelium is embedded in adipose tissue with relatively few fibroblasts and blood vessels present, while human epithelium is embedded in a highly collagenous stroma, populated with intralobular fibroblasts and an intricate network of blood vessels (Ronnov-Jessen et al., 1996), thus implying that different types of epithelial-stromal crosstalk may take place. Measures have, however, been taken to address this prominent difference which in many respects may reduce the physiological relevance of the mouse model. The mouse fat pad can be "humanized" by the inclusion of human fibroblasts prior to transplantation of human epithelial and stromal cells into the cleared fat pad of NOD/ SCID immune-compromised mice (Kuperwasser et al., 2004). Mammary fat pads are cleared at three weeks of age, and up to two weeks later, human fibroblasts can be injected, and the gland is then ready to receive transplantation immediately thereafter. The systemic hormonal environment during puberty is sufficient to promote epithelial proliferation and differentiation, while at the same time recapitulating critical aspects of morphogenesis of normal breast as well as breast cancer (Kuperwasser et al., 2004). In this assay, candidate stem cells from the human breast gland, isolated based on increased aldehyde dehydrogenase activity, have been shown to give rise to outgrowths containing both luminal and myoepithelial cells (Ginestier et al., 2007). Also, another in vivo assay not directly employing the mammary gland microenvironment but nevertheless well suited for studying outgrowth potential of human breast epithelial cells is of relevance for the study of mammary stem cells. Here, isolated cells or tissue fragments are combined with stromal cells in collagen gels and then placed under the highly vascularised subrenal capsule of immune-compromised mice (Eirew et al., 2008; Parmar et al., 2002). Under these conditions, basal cells have the highest ability of generating physiologically relevant outgrowths as opposed to luminal cells (Eirew et al., 2008), which is in good accordance with previously published reports on mouse mammary stem cells (Shackleton et al., 2006; Sleeman et al., 2006; Stingl et al., 2006). However, no specific subpopulation within the whole basal compartment was defined as being enriched for candidate stem cells but rather it was merely shown that the stem cell activity within the human breast gland co-segregates with the basal lineage when tested under these in vivo settings. In fact, currently, not much is known about cellular heterogeneity among basal cells, neither within the human nor the mouse mammary gland. This is in contrast to current knowledge of a hierarchy among luminal cells, where several distinct subpopulations with different functional properties have been defined (Asselin-Labat et al., 2007; Sleeman et al., 2007). That the stromal microenvironment indeed is important in these in vivo assays is further emphasized by the fact that without co-inoculation of fibroblasts, epithelial outgrowths do not arise in the transplants (Eirew et al., 2008; Kuperwasser et al., 2004; Parmar et al., 2002). The crucial role of the microenvironment in fate determination of transplanted mouse mammary cells in the cleared mammary fat pad has also recently been nicely demonstrated (Bai and Rohrschneider, 2010). When alveolar bud stem cells isolated from the pregnant state were injected into pubertal cleared fat pads, they switched on a pubertal developmental program and started forming a branched ductal tree (Bai and Rohrschneider, 2010), and thus responded to the new microenvironment rather than recapitulating their current developmental stage. These observations clearly demonstrate that the golden standard assay for mammary stem cells, the cleared mammary fat pad, has limitations.

The stem cell properties of the transplanted cells are apparently under the control of the niche signals provided by the microenvironment, which might undergo changes in a temporal and spatial manner. Therefore, the fact that some subpopulations of cells exhibit a higher regenerative potential than others may merely reflect that the cells in question are able to respond more efficiently to the niche signals currently present. Moreover, a cell's ability to respond to the microenvironment may depend on its surface marker profile. For example, a high expression of integrins has been suggested to help cells adhere to the extracellular matrix under transplantation, providing the necessary signals for survival and expansion (reviewed by (Smith, 2006)). Consequently, the regenerative potential of different cell subpopulations may be considered as the combinatorial result of their stem cell properties and their ability to respond to the surrounding microenvironment. Therefore, it could be argued that the lack of a positive outcome in a transplantation assay might not necessarily mean that the cells lack multipotency or are terminally differentiated but rather that the assay in question is not suitable for revealing their true characteristics.

In conclusion, while many issues remain to be investigated and await the identification of novel markers to reveal mammary stem cells and their niches as well as development of more appropriate models to address questions specifically about the human gland, the search of the stem cell within the mammary epithelium has nevertheless begun to establish cellular hierarchies (Sleeman et al., 2007; Villadsen et al., 2007). These findings in turn spur the search of the cellular origin of cancer, hopefully leading to novel strategies of diagnosis, prognosis and treatment of human breast cancer.

\section{Acknowledgements}

This work was supported by grants from the Danish Cancer Society (DP07063 and R20-A1149-10-S2); The European Commission (Contract no. LSHC-CT-2006-037632 to EuroCSC); The Danish Agency for Science and Technology Innovation (2107-05-0006 to DANED, 10-092798 to DANSTEM and 08-045450 to Danish-Japanese Cooperative Research); Dansk Kræftforskningsfond; the Lundbeck Foundation; the Novo Nordic Foundation; the Simon Spies Foundation, The John and Birthe Meyer Foundation and Fru Astrid Thaysens Legat for Lægevidenskabelig Grundforskning.

\section{References}

AL-HAJJ, M., WICHA, M. S., BENITO-HERNANDEZ, A., MORRISON, S. J., and CLARKE, M. F. (2003). Prospective identification of tumorigenic breast cancer cells. Proc Natl Acad Sci U S A 100: 3983-3988.

ALVI, A. J., CLAYTON, H., JOSHI, C., ENVER, T., ASHWORTH, A., VIVANCO, M. M., DALE, T. C., and SMALLEY, M. J. (2003). Functional and molecular characterisation of mammary side population cells. Breast Cancer Res 5: R1-8.

ASSELIN-LABAT, M. L., SHACKLETON, M., STINGL, J., VAILLANT, F., FORREST, N C., EAVES, C. J., VISVADER, J. E., and LINDEMAN, G. J. (2006). Steroid hormone receptor status of mouse mammary stem cells. J Natl Cancer Inst 98: 1011-1014.

ASSELIN-LABAT, M. L., SUTHERLAND, K. D., BARKER, H., THOMAS, R., SHACKLETON, M., FORREST, N. C., HARTLEY, L., ROBB, L., GROSVELD, F. G., VAN DER WEES, J., LINDEMAN, G. J., and VISVADER, J. E. (2007). Gata-3 is an essential regulator of mammary-gland morphogenesis and luminal-cell differentiation. Nat Cell Biol 9: 201-209.

ASSELIN-LABAT, M. L., VAILLANT, F., SHERIDAN, J. M., PAL, B., WU, D., SIMPSON, E. R., YASUDA, H., SMYTH, G. K., MARTIN, T. J., LINDEMAN, G. J. and VISVADER, J. E. (2010). Control of mammary stem cell function by steroid 
hormone signalling. Nature 465: 798-802.

BAI, L., and ROHRSCHNEIDER, L. R. (2010). s-SHIP promoter expression marks activated stem cells in developing mouse mammary tissue. Genes Dev24: 1882-1892.

BLANPAIN, C., LOWRY, W. E., GEOGHEGAN, A., POLAK, L., and FUCHS, E. (2004). Self-renewal, multipotency, and the existence of two cell populations within an epithelial stem cell niche. Cell 118: 635-648.

BOOTH, B. W., BOULANGER, C. A., and SMITH, G. H. (2008). Selective segregation of DNA strands persists in long-label-retaining mammary cells during pregnancy. Breast Cancer Res 10: R90.

BOOTH, B. W., and SMITH, G. H. (2006). Estrogen receptor-alpha and progesterone receptor are expressed in label-retaining mammary epithelial cells that divide asymmetrically and retain their template DNA strands. Breast Cancer Res 8: R49.

BOULANGER, C. A., WAGNER, K. U., and SMITH, G. H. (2005). Parity-induced mouse mammary epithelial cells are pluripotent, self-renewing and sensitive to TGF-beta1 expression. Oncogene 24: 552-560.

BRISKEN, C., HEINEMAN, A., CHAVARRIA, T., ELENBAAS, B., TAN, J., DEY, S. K., MCMAHON, J. A., MCMAHON, A. P., and WEINBERG, R. A. (2000). Essential function of Wnt-4 in mammary gland development downstream of progesterone signaling. Genes Dev 14: 650-654.

BRISKEN, C., PARK, S., VASS, T., LYDON, J. P., O'MALLEY, B. W., and WEINBERG, R. A. (1998). A paracrine role for the epithelial progesterone receptor in mammary gland development. Proc Natl Acad Sci U S A 95: 5076-5081.

CHEPKO, G., and SMITH, G. H. (1997). Three division-competent, structurallydistinct cell populations contribute to murine mammary epithelial renewal. Tissue Cell 29: 239-253

CIARLONI, L., MALLEPELL, S., and BRISKEN, C. (2007). Amphiregulin is an essential mediator of estrogen receptor alpha function in mammary gland development. Proc Natl Acad Sci U S A 104: 5455-5460.

CLARKE, R. B., SPENCE, K., ANDERSON, E., HOWELL, A., OKANO, H., and POTTEN, C. S. (2005). A putative human breast stem cell population is enriched for steroid receptor-positive cells. Dev Biol 277: 443-456.

DANIEL, C. W., AIDELLS, B. D., MEDINA, D., and FAULKIN, L. J., JR. (1975). Unlimited division potential of precancerous mouse mammary cells after spontaneous or carcinogen-induced transformation. Fed Proc 34: 64-67.

DANIEL, C. W., DE OME, K. B., YOUNG, J. T., BLAIR, P. B., and FAULKIN, L. J., JR. (1968). The in vivo life span of normal and preneoplastic mouse mammary glands: a serial transplantation study. Proc Natl Acad Sci U S A 61: 53-60.

DANIEL, C. W., YOUNG, L. J., MEDINA, D., and DEOME, K. B. (1971). The influence of mammogenic hormones on serially transplanted mouse mammary gland. Exp Gerontol 6: 95-101.

DEOME, K. B., FAULKIN, L. J., JR., BERN, H. A., and BLAIR, P. B. (1959). Development of mammary tumors from hyperplastic alveolar nodules transplanted into gland-free mammary fat pads of female C3H mice. Cancer Res 19: 515-520.

DEY, D., SAXENA, M., PARANJAPE, A. N., KRISHNAN, V., GIRADDI, R., KUMAR, M. V., MUKHERJEE, G., and RANGARAJAN, A. (2009). Phenotypic and functional characterization of human mammary stem/progenitor cells in long term culture. PLoS One 4: e5329.

DONTU, G., ABDALLAH, W. M., FOLEY, J. M., JACKSON, K. W., CLARKE, M. F., KAWAMURA, M. J., and WICHA, M. S. (2003). In vitro propagation and transcriptional profiling of human mammary stem/progenitorcells. Genes Dev17:1253-1270.

DONTU, G., JACKSON, K. W., MCNICHOLAS, E., KAWAMURA, M. J., ABDALLAH, W. M., and WICHA, M. (2004). Role of Notch signaling in cell-fate determination of human mammary stem/progenitor cells. Breast Cancer Res 6: R605-R615.

EIREW, P., STINGL, J., RAOUF, A., TURASHVILI, G., APARICIO, S., EMERMAN, J. T., and EAVES, C. J. (2008). A method for quantifying normal human mammary epithelial stem cells with in vivo regenerative ability. Nat Med 14: 1384-1389.

FERNANDEZ-GONZALEZ, R., ILLA-BOCHACA, I., WELM, B. E., FLEISCH, M. C., WERB, Z., ORTIZ-DE-SOLORZANO, C., and BARCELLOS-HOFF, M. H. (2009). Mapping mammary gland architecture using multi-scale in situ analysis. Integr Biol (Camb) 1: 80-89.

FUCHS, E., TUMBAR, T., and GUASCH, G. (2004). Socializing with the neighbors: stem cells and their niche. Cell 116: 769-778.

GALLAHAN, D., JHAPPAN, C., ROBINSON, G., HENNIGHAUSEN, L., SHARP, R., KORDON, E., CALLAHAN, R., MERLINO, G., and SMITH, G. H. (1996). Expression of a truncated Int3 gene in developing secretory mammary epithelium specifically retards lobular differentiation resulting in tumorigenesis. Cancer Res56:1775-1785.
GINESTIER, C., HUR, M. H., CHARAFE-JAUFFRET, E., MONVILLE, F., DUTCHER, J., BROWN, M., JACQUEMIER, J., VIENS, P., KLEER, C. G., LIU, S., SCHOTT, A., HAYES, D., BIRNBAUM, D., WICHA, M., and DONTU, G. (2007). ALDH1 Is a Marker of Normal and Malignant Human Mammary Stem Cells and a Predictor of Poor Clinical Outcome. Cell Stem Cell 1: 555-567.

GUDJONSSON, T., VILLADSEN, R., NIELSEN, H. L., RONNOV-JESSEN, L., BISSELL, M. J., and PETERSEN, O. W. (2002). Isolation, immortalization, and characterization of a human breast epithelial cell line with stem cell properties. Genes Dev 16: 693-706.

HARRISON, H., FARNIE, G., BRENNAN, K. R., and CLARKE, R. B. (2010). Breast cancer stem cells: something out of notching? Cancer Res 70: 8973-8976.

KELLY, R. K., OLSON, D. L., SUN, Y., WEN, D., WORTHAM, K. A., ANTOGNETTI, G., CHEUNG, A. E., OROZCO, O. E., YANG, L., BAILLY, V., and SANICOLA, M. (2011). An antibody-cytotoxic conjugate, BIIB015, is a new targeted therapy for Cripto positive tumours. Eur $J$ Cancer

KORDON, E. C., and SMITH, G. H. (1998). An entire functional mammary gland may comprise the progeny from a single cell. Development 125: 1921-1930.

KOUROS-MEHR, H., SLORACH, E. M., STERNLICHT, M. D., and WERB, Z. (2006). GATA-3 maintains the differentiation of the luminal cell fate in the mammary gland. Cell 127: 1041-1055

KUPERWASSER, C., CHAVARRIA, T., WU, M., MAGRANE, G., GRAY, J. W., CAREY, L., RICHARDSON, A., and WEINBERG, R. A. (2004). Reconstruction of functionally normal and malignant human breast tissues in mice. Proc Natl Acad Sci U S A 101: 4966-4971.

LIM, E., VAILLANT, F., WU, D., FORREST, N. C., PAL, B., HART, A. H., ASSELINLABAT, M. L., GYORKI, D. E., WARD, T., PARTANEN, A., FELEPPA, F., HUSCHTSCHA, L. I., THORNE, H. J., FOX, S. B., YAN, M., FRENCH, J. D., BROWN, M. A., SMYTH, G. K., VISVADER, J. E., and LINDEMAN, G. J. (2009). Aberrant luminal progenitors as the candidate target population for basal tumor development in BRCA1 mutation carriers. Nat Med 15: 907-913.

LIU, S., DONTU, G., MANTLE, I. D., PATEL, S., AHN, N. S., JACKSON, K. W., SURI P., and WICHA, M. S. (2006). Hedgehog signaling and Bmi-1 regulate self-renewal of normal and malignant human mammary stem cells. Cancer Res 66:6063-6071.

MALLEPELL, S., KRUST, A., CHAMBON, P., and BRISKEN, C. (2006). Paracrine signaling through the epithelial estrogen receptor alpha is required for proliferation and morphogenesis in the mammary gland. Proc Natl Acad Sci U S A 103: 2196-2201.

MATULKA, L. A., TRIPLETT, A. A., and WAGNER, K. U. (2007). Parity-induced mammary epithelial cells are multipotent and express cell surface markers associated with stem cells. Dev Biol 303: 29-44.

MOLYNEUX, G., GEYER, F. C., MAGNAY, F. A., MCCARTHY, A., KENDRICK, H., NATRAJAN, R., MACKAY, A., GRIGORIADIS, A., TUTT, A., ASHWORTH, A., REIS-FILHO, J. S., and SMALLEY, M. J. (2010). BRCA1 basal-like breast cancers originate from luminal epithelial progenitors and not from basal stem cells. Cell Stem Cell 7: 403-417.

MORRIS, R. J., and POTTEN, C. S. (1999). Highly persistent label-retaining cells in the hair follicles of mice and their fate following induction of anagen. $J$ Invest Dermatol 112: 470-475.

MULAC-JERICEVIC, B., LYDON, J. P., DEMAYO, F. J., and CONNEELY, O. M. (2003) Defective mammary gland morphogenesis in mice lacking the progesterone receptor B isoform. Proc Natl Acad Sci U S A 100: 9744-9749.

PARMAR, H., YOUNG, P., EMERMAN, J. T., NEVE, R. M., DAIRKEE, S., and CUNHA, G. R. (2002). A novel method for growing human breast epithelium in vivo using mouse and human mammary fibroblasts. Endocrinology 143: 4886-4896.

PETERSEN, O. W., and POLYAK, K. (2010). Stem cells in the human breast. Cold Spring Harb Perspect Biol 2: a003160.

PETERSEN, O. W., RONNOV-JESSEN, L., HOWLETT, A. R., and BISSELL, M. J. (1992). Interaction with basement membrane serves to rapidly distinguish growth and differentiation pattern of normal and malignant human breast epithelial cells. Proc Natl Acad Sci U S A 89: 9064-9068.

POTTEN, C. S., BOOTH, C., and PRITCHARD, D. M. (1997). The intestinal epithelial stem cell: the mucosal governor. Int J Exp Pathol 78: 219-243.

PROIA, T. A., KELLER, P. J., GUPTA, P. B., KLEBBA, I., JONES, A. D., SEDIC, M., GILMORE, H., TUNG, N., NABER, S. P., SCHNITT, S., LANDER, E. S., and KUPERWASSER, C. (2011). Genetic predisposition directs breast cancer phenotype by dictating progenitor cell fate. Cell Stem Cell 8: 149-163. 
REYNOLDS, B. A., and WEISS, S. (1996). Clonal and population analyses demonstrate that an EGF-responsive mammalian embryonic CNS precursor is a stem cell. Dev Biol 175: 1-13.

RICHERT, M. M., SCHWERTFEGER, K. L., RYDER, J. W., and ANDERSON, S. M. (2000). An atlas of mouse mammary gland development. J Mammary Gland Biol Neoplasia 5: 227-241.

RONNOV-JESSEN, L., PETERSEN, O. W., and BISSELL, M. J. (1996). Cellular changes involved in conversion of normal to malignant breast: importance of the stromal reaction. Physiol Rev 76: 69-125.

RUSSO, J., and RUSSO, I. H. (1987). The mammary gland: development, regulation and function. New York: Plenum Press.

RUSSO, J., and RUSSO, I. H. (2004). Development of the human breast. Maturitas 49: $2-15$.

SHACKLETON, M., VAILLANT, F., SIMPSON, K. J., STINGL, J., SMYTH, G. K., ASSELIN-LABAT, M. L., WU, L., LINDEMAN, G. J., and VISVADER, J. E. (2006). Generation of a functional mammary gland from a single stem cell. Nature 439: 84-88.

SHININ, V., GAYRAUD-MOREL, B., GOMES, D., and TAJBAKHSH, S. (2006). Asymmetric division and cosegregation of template DNA strands in adult muscle satellite cells. Nat Cell Biol 8: 677-687.

SHIPITSIN, M., CAMPBELL, L. L., ARGANI, P., WEREMOWICZ, S., BLOUSHTAINQIMRON, N., YAO, J., NIKOLSKAYA, T., SEREBRYISKAYA, T., BEROUKHIM, R., HU, M., HALUSHKA, M. K., SUKUMAR, S., PARKER, L. M., ANDERSON, K. S., HARRIS, L. N., GARBER, J. E., RICHARDSON, A. L., SCHNITT, S. J., NIKOLSKY, Y., GELMAN, R. S., and POLYAK, K. (2007). Molecular definition of breast tumor heterogeneity. Cancer Cell 11: 259-273.

SILBERSTEIN, G. B. (2001). Postnatal mammary gland morphogenesis. Microsc Res Tech 52: 155-162.

SLEEMAN, K. E., KENDRICK, H., ASHWORTH, A., ISACKE, C. M., and SMALLEY, M. J. (2006). CD24 staining of mouse mammary gland cells defines lumina epithelial, myoepithelial/basal and non-epithelial cells. Breast Cancer Res 8: R7.

SLEEMAN, K. E., KENDRICK, H., ROBERTSON, D., ISACKE, C. M., ASHWORTH, A., and SMALLEY, M. J. (2007). Dissociation of estrogen receptor expression and in vivo stem cell activity in the mammary gland. J Cell Biol 176: 19-26.

SMALLEY, M. J., TITLEY, J., and O'HARE, M. J. (1998). Clonal characterization of mouse mammary luminal epithelial and myoepithelial cells separated by fluorescence-activated cell sorting. In vitro Cell Dev Biol Anim 34: 711-721.

SMITH, G. H. (1996). Experimental mammary epithelial morphogenesis in an in vivo model: evidence for distinct cellular progenitors of the ductal and lobular phenotype. Breast Cancer Res Treat 39: 21-31.

SMITH, G. H. (2005). Label-retaining epithelial cells in mouse mammary gland divide asymmetrically and retain their template DNAstrands. Development 132:681-687.

SMITH, G. H. (2006). Mammary stem cells come of age, prospectively. Trends Mol Med 12: 287-289.

SMITH, G. H., and CHEPKO, G. (2001). Mammary epithelial stem cells. Microsc Res Tech 52: 190-203.

SMITH, G. H., and MEDINA, D. (1988). A morphologically distinct candidate for an epithelial stem cell in mouse mammary gland. J Cell Sci 90: 173-183.

SMITH, G. H., and MEDINA, D. (2008). Re-evaluation of mammary stem cell biology based on in vivo transplantation. Breast Cancer Res 10: 203.

SMITH, G. H., STRICKLAND, P., and DANIEL, C. W. (2002). Putative epithelial stem cell loss corresponds with mammary growth senescence. Cell Tissue Res 310: 313-320.

STINGL, J., EAVES, C. J., ZANDIEH, I., and EMERMAN, J. T. (2001). Characterization of bipotent mammary epithelial progenitor cells in normal adult human breast tissue. Breast Cancer Res Treat 67: 93-109.
STINGL, J., EIREW, P., RICKETSON, I., SHACKLETON, M., VAILLANT, F., CHOI, D., LI, H. I., and EAVES, C. J. (2006). Purification and unique properties of mammary epithelial stem cells. Nature 439: 993-997.

STRIZZI, L., POSTOVIT, L. M., MARGARYAN, N. V., SEFTOR, E. A., ABBOTT, D. E., SEFTOR, R. E., SALOMON, D. S., and HENDRIX, M. J. (2008). Emerging roles of nodal and Cripto-1: from embryogenesis to breast cancer progression. Breast Dis 29: 91-103.

SUN, P., YUAN, Y., LI, A., LI, B., and DAI, X. (2010). Cytokeratin expression during mouse embryonic and early postnatal mammary gland development. Histochem Cell Biol 133: 213-221

SUN, Y., STRIZZI, L., RAAFAT, A., HIROTA, M., BIANCO, C., FEIGENBAUM, L., KENNEY, N., WECHSELBERGER, C., CALLAHAN, R., and SALOMON, D. S. (2005). Overexpression of human Cripto-1 in transgenic mice delays mammary gland development and differentiation and induces mammary tumorigenesis. Am J Pathol 167: 585-597.

TADDEI, I., DEUGNIER, M. A., FARALDO, M. M., PETIT, V., BOUVARD, D., MEDINA D., FASSLER, R., THIERY, J. P., and GLUKHOVA, M. A. (2008). Beta1 integrin deletion from the basal compartment of the mammary epithelium affects stem cells. Nat Cell Biol 10: 716-722.

TSAI, Y. C., LU, Y., NICHOLS, P. W., ZLOTNIKOV, G., JONES, P. A., and SMITH, H. S. (1996). Contiguous patches of normal human mammary epithelium derived from a single stem cell: implications for breast carcinogenesis. Cancer Res 56: 402-404.

VAILLANT, F., LINDEMAN, G. J., and VISVADER, J. E. (2011). Jekyll or Hyde: does Matrigel provide a more or less physiological environment in mammary repopulating assays? Breast Cancer Res 13: 108.

VAN KEYMEULEN, A., ROCHA, A.S., OUSSET, M. ,BECK, B., BOUVENCOURT, G. ROCK, J., SHARMA, N., DEKONINCK, S., and BLANPAIN, C. (2011). Distinct stem cells contribute to mammary gland development and maintainence. Nature 479: 189-193.

VILLADSEN, R., FRIDRIKSDOTTIR, A. J., RONNOV-JESSEN, L., GUDJONSSON, T., RANK, F., LABARGE, M. A., BISSELL, M. J., and PETERSEN, O. W. (2007) Evidence for a stem cell hierarchy in the adult human breast. J Cell Biol177:87-101.

WAGNER, K. U., BOULANGER, C. A., HENRY, M. D., SGAGIAS, M., HENNIGHAUSEN, L., and SMITH, G. H. (2002). An adjunct mammary epithelial cell population in parous females: its role in functional adaptation and tissue renewal. Development 129: 1377-1386.

WATSON, C. J., and KHALED, W. T. (2008). Mammary development in the embryo and adult: a journey of morphogenesis and commitment. Development 135: 995-1003.

WECHSELBERGER, C., STRIZZI, L., KENNEY, N., HIROTA, M., SUN, Y., EBERT, A. OROZCO, O., BIANCO, C., KHAN, N. I., WALLACE-JONES, B., NORMANNO, N., ADKINS, H., SANICOLA, M., and SALOMON, D. S. (2005). Human Cripto-1 overexpression in the mouse mammary gland results in the development of hyperplasia and adenocarcinoma. Oncogene 24: 4094-4105

WELM, B. E., TEPERA, S. B., VENEZIA, T., GRAUBERT, T. A., ROSEN, J. M., and GOODELL, M. A. (2002). Sca-1 (pos) cells in the mouse mammary gland represent an enriched progenitor cell population. Dev Biol 245: 42-56.

WIESEN, J. F., YOUNG, P., WERB, Z., and CUNHA, G. R. (1999). Signaling through the stromal epidermal growth factor receptor is necessary for mammary ducta development. Development 126: 335-344.

WILLIAMS, J. M., and DANIEL, C. W. (1983). Mammary ductal elongation: differentiation of myoepithelium and basal lamina during branching morphogenesis. Dev Biol 97: 274-290.

ZHOU, S., SCHUETZ, J. D., BUNTING, K. D., COLAPIETRO, A. M., SAMPATH, J., MORRIS, J. J., LAGUTINA, I., GROSVELD, G. C., OSAWA, M., NAKAUCHI, H., and SORRENTINO, B. P. (2001). The ABC transporter Bcrp1/ABCG2 is expressed in a wide variety of stem cells and is a molecular determinant of the side-population phenotype. Nat Med 7: 1028-1034 


\section{Further Related Reading, published previously in the Int. J. Dev. Biol.}

\section{Cancer stem cells and angiogenesis}

Yue Zhao, Qi Bao, Andrea Renner, Peter Camaj, Martin Eichhorn, Ivan Ischenko, Martin Angele, Axel Kleespies, Karl-Walter Jauch and Christiane Bruns

Int. J. Dev. Biol. (2011) 55: 477-482 (doi: 10.1387/ijdb.103225yz)

\section{Hematopoietic stem cell development in the placenta}

Christos Gekas, Katrin E. Rhodes, Ben Van Handel, Akanksha Chhabra, Masaya Ueno and Hanna K.A. Mikkola Int. J. Dev. Biol. (2010) 54: 1089-1098

Novel methods for determining hematopoietic stem and progenitor cell emergence in the murine yolk sac Christopher T. Lux and Mervin C. Yoder Int. J. Dev. Biol. (2010) 54: 1003-1009

Human conjunctival epithelial precursor cells and their progeny in 3D organotypic culture Alfredo Rosellini, Sandra Papini, Claudio Giannarini, Marco Nardi and Roberto P. Revoltella Int. J. Dev. Biol. (2007) 51: 739-743

\section{Plant stem cell niches}

Yvonne Stahl and Rüdiger Simon

Int. J. Dev. Biol. (2005) 49: 479-489

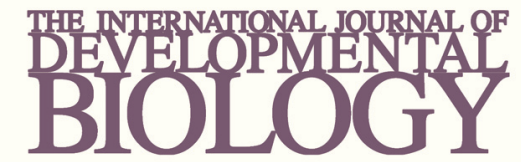

Volume 54 Nos. 6/7

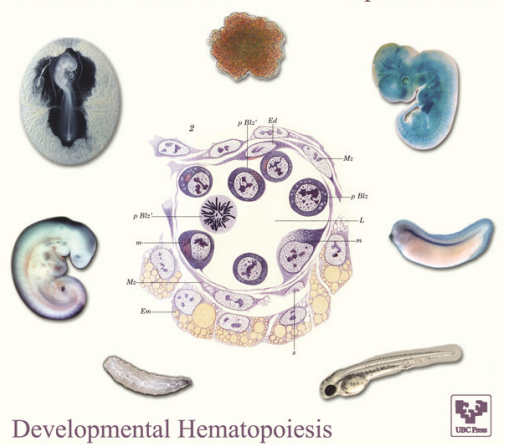

5 yr ISI Impact Factor $(2010)=2.961$

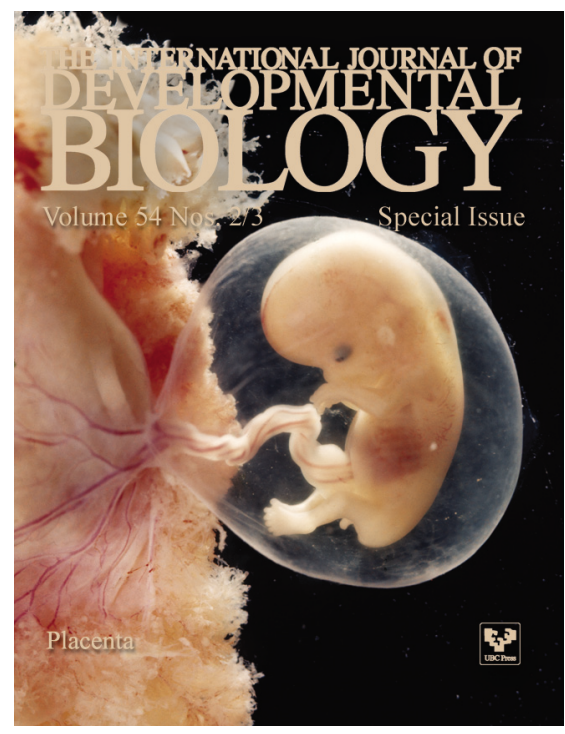

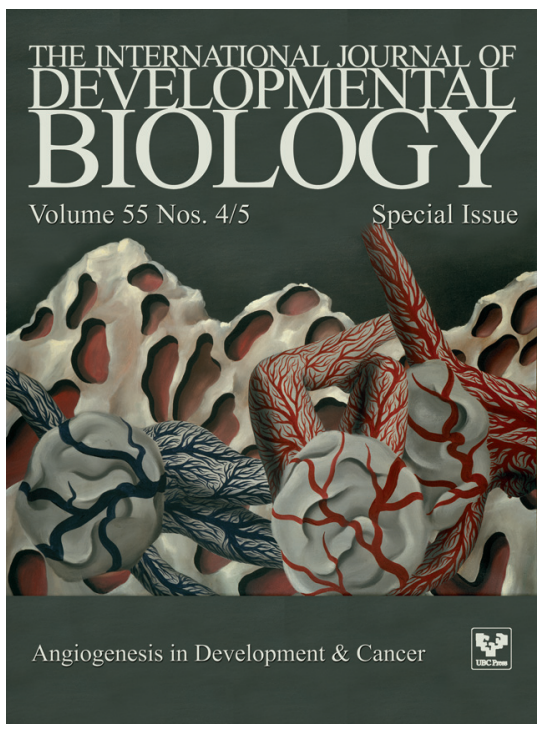

